\title{
RINTISAN SEKOLAH BERSTANDAR INTERNASIONAL: Antara Cita \& Fakta
}

\author{
Syamsul Ma'arif \\ UNY Yogyakarta \\ e-mail: syamsulmaarif1974@yahoo.co.id
}

\begin{abstract}
This paper is the result of research on junior school of RSBI 2 Semarang. By using qualitative descriptive research methods and approaches case can be concluded that no other RSBI founding purpose is only to get to quality education in Indonesia and are able to compete at international level. Moreover, the fact that Indonesia is part of the life of a globalized world, it is in harmony with the global demands should be considered in order to have an accredited educational international. Where the quality of our educational institution recognized internationally. Indonesia does not need education "embarrassed" let alone to be arrogant in the face of the criteria used at the international level. Although in practice RSBI, faces a number of problems both economic, psychological, cultural and governance management.
\end{abstract}

\begin{abstract}
$* * *$
Artikel ini merupakan hasil penelitian di SMP RSBI 2 Semarang. Dengan menggunakan pendekatan deskriptif kualitatif dapat disimpulkan bahwa tujuan pendirian RSBI tidak lain adalah hanya untuk mendapatkan pendidikan yang berkualitas di Indonesia dan mampu bersaing di tingkat internasional. Selain itu, fakta bahwa Indonesia adalah bagian dari kehidupan dunia yang mengglobal. Selaras dengan tuntutan global itu adalah harus dipertimbangkan dalam rangka untuk memiliki pendidikan yang terakreditasi secara internasional. Dimana kualitas lembaga pendidikan kita diakui secara internasional. Meskipun dalam prakteknya RSBI, menghadapi sejumlah masalah baik manajemen ekonomi, psikologis, budaya, dan pemerintahan.
\end{abstract}

Keywords: cita, praksis, problematika RSBI 


\section{A. Pendahuluan}

Segala upaya harus dilaksanakan dalam rangka mencari terobosan mendongkrak mutu dan kualitas sumberdaya manusia Indonesia. Terutama menyangkut bidang pendidikan, sebagai investasi nyata bagi perubahan masa depan yang lebih baik. Penyemaian cita-cita dan merealisasikan mimpi menjadi bangsa yang handal, bermartabat, memiliki daya saing tinggi di tingkat global-hanya bisa diraih lewat penyelenggaraan pendidikan yang bermutu dan berkualitas. Dalalam kontek ini, perubahan system pendidikan yang lebih baik menjadi sebuah keniscayaan. Sebab, if you don't change, you die!

Apalagi masa depan adalah sebuah masa yang menuntut manusia dengan segala skill dan kompetensi demi survivalitasnya. Bangsa yang memiliki tingkat kecerdasan rendah sukar untuk dapat menjawab tuntutan global. ${ }^{1}$ Bisa dikatakan manusia dengan kompetensi profesional adalah ciri dari manusia abad mendatang. Sebuah masa yang ditandai dengan proses informatisasi yang cepat karena kemajuan teknologi dan horizon kehidupan di planit ini semakin mengerut. Semua yang hidup di bumi ini, tidak bisa terisolir dengan realitas dan kebutuhan orang dan masyarakat lain. Pendek kata, globalisasi adalah sebuah masa yang penuh tantangan sekaligus menuntut kesetikawanan terhadap manusia lain. Pendidikan harus mampu membawa individu kepada kesadaran global ini.

Melihat kenyataan tersebut, hanya lembaga pendidikan yang berkualitas dan memenuhi tuntutan masyarakat yang akan tetap survive. Namun demikian, pengertian kompetisi dalam dunia pendidikan ini tidak sama dengan kompetisi dalam bidang industri. Kompetisi dalam dunia pendidikan hanya terbatas dalam memberikan kualitas layanan pendidikan dan meningkatkan mutu lulusannya, bukan untuk mencari keuntungan sebanyak banyaknya. $^{2}$

Mengantisipasi dampak globalisasi tersebut, agar tetap bertahan setiap organisasi harus melakukan perubahan paradigma, dari old work order menjadi new flexible work order, dari memandang dunia ini penuh keteraturan

1 Peningkatan rasa tanggung jawab global perlu kecerdasan yang memadai. Lihat H.A.R. Tilaar, Manajemen Pendidikan Nasional; Kajian Pendidikan Masa Depan, (Bandung: Remaja Rosdakarya, 1999), h. 4.

2 Nathaniel H. Karol \& Sigmund G. Ginsburg, Managing The Higher Education Enterprise, p. 6. 
menjadi dunia yang turbulen, dari organisasi Newtonian menjadi organisasi Quantum, dari economical capital menjadi intellectual capital. ${ }^{3}$ Sehingga segala bentuk perubahan yang dilakukan oleh sebuah lembaga dapat dikatan sebagai ihktiyar mencari yang lebih baik dan perwujudan akan keberadaannya.

Melihat kenyataan tersebut fenomena SBI/RSBI boleh dikatakan sebagai alternatif pendidikan dalam merespon tuntutan globalisasi. Kalau pendidikan kita tidak segera meningkatkan kualitas dan prestasi secara massif dan akseleratif, habislah pendidikan dinegeri ini tergilas oleh roda globalisasi yang berputar cepat.4 Oleh sebab itu, fokus pembahasan dalam tulisan ini lebih menyoroti tentang RSBI, untuk mengetahui lebih detail keberadaanya dan memberikan diskripsi praktik pembelajaranya di Negara kita. Pengambilan istilah RSBI daripada SBI, bukan tanpa maksud. Hal ini disebabkan masih pro-kontra mengenai status dan pelabelan diantara keduanya. Meskipun harus diakui, antara SBI/RSBI sebetulnya mempunyai hubungan yang sangat erat dari aspek standar mutunya. Sebab RSBI merupakan cikal bakal menjadi SBI. Apa sebenarnya RSBI dan bagaimana motivasi didirikanya sekolah tersebut dinegara kita? Disinilah letak pentingnya tulisan berikut untuk memberikan peta pemahaman tentang seputar RSBI, dari aspek pengertian \& karakteristik, kompetensi lulusan, problematika dan proses belajar mengajarnya.

\section{B. Pengertian \& Karakteristik RSBI}

Untuk mendukung program pemerintah dalam merealisasikan UndangUndang No. 20 Tahun 2003 tentang Sistem Pendidikan Nasional Pasal 50 ayat 3,5 PP No. 19 Pasal 61 ayat 1, serta Renstra Depdiknas periode 2005-2009 mengenai kebijakan dalam peningkatan mutu, relevansi dan daya saing, salah satunya yaitu dengan menyelenggarakan Rintisan Sekolah Bertaraf Inter-

${ }^{3}$ Andi Haris Prabwa, dkk., Paradigma Pengembangan Kurikulum 2000, (Surakarta: UMS Press, 2002), h. 41.

4 Jamal Ma'mur Asmani, Tips Efektif Menjadi Sekolah Berstandar Nasional \& Internasional, (Yogyakarta: Harmoni, 2006), h. 169-170.

${ }^{5}$ Isi dari pasal tersebut adalah: pemerintah dan/atau pemerintah daerah menyelenggarakan sekurang-kurangnya satu satuan pendidikan pada semua jenjang pendidikan untuk dikembangkan menjadi satuan pendidikan bertaraf internasional. 
nasional (RSBI). RSBI ini merupakan salah satu dari empat model penyelenggaraan pendidikan dasar dan menengah di Indonesia.

Sekolah model pertama adalah sekolah potensional yaitu; sekolah yang masih banyak kekurangan/kelemahan untuk memenuhi kriteria sekolah yang sesuai dengan Standar Pendidikan Nasional. Kedua, kategori Sekolah Standar Nasional. Ketiga, kategori Sekolah Standar Nasional dan memiliki keunggulan lokal. Sedangkan sekolah kategori keempat adalah Sekolah Bertaraf Internasional (SBI). ${ }^{6}$

Sekolah bisa disebut dengan SBI jika sekolah ini telah memenuhi Standar Nasional Pendidikan pada tiap aspeknya, meliputi: standar kompetensi lulusan, isi, proses, pendidik dan tenaga kependidikan, sarana dan prasarana, pembiayaan, pengelolaan, penilaian dan telah menyelenggarakan serta menghasilkan lulusan dengan ciri keinternasionalan. ${ }^{7}$

Sebelum menjadi sekolah SBI sekolah biasanya masih dikategorikan sebagai RSBI. Rintisan ini bersifat sementara saja sampai akhirnya benarbenar menjadi SBI. Sekolah yang masuk kategori RSBI adalah sekolah-sekolah yang dipersiapkan secara bertahap melalui pembinaan oleh pemerintah dan stakeholders, dalam jangka waktu tertentu yaitu empat tahun diharapkan sekolah tersebut mampu dan memenuhi kriteria untuk menjadi Sekolah Bertaraf Internasional (SBI). ${ }^{8}$ Dalam konteks ini Direktorat Pembinaan SMP bersama dengan Dinas Pendidikan Provinsi dan Kabupaten/Kota pada dasarnya bertugas untuk melaksanakan uji coba atau melaksanakan pembinaan awal menuju sekolah yang bertaraf internasional, dan selanjutnya secara bertahap dapat mencapai standar sekolah yang benar-benar bertaraf internasional.

Secara garis besar sekolah yang masuk kategori RSBI memiliki spesifikasi sebagai berikut:

1. Landasan Hukum

a. UU No. 20 Tahun 2003 ps 50 UU No. 32 Tahun 2004: Pemerintahan Pusat dan Daerah.

${ }^{6}$ Zainal Aqib, Membangun Prestise SSN \& SBI, (Bandung: Yrama Widya, 2010), h. 4.

7 Bisa dilihat pengertian sekolah bertaraf internasional menurut buku panduan yang dikeluarkan oleh Diknas Provinsi Jawa Tengah, tahun 2007/2008.

8 Departemen Pendidikan Nasional, Pedoman Penjamin Mutu Sekolah/Madrasah Bertaraf Internasional pada Jenjang Pendidikan Dasar dan Menengah, (Jakarta: Badan Penelitian dan Pengembangan Departemen Pendidikan Nasional, 2007), h. 5. 
b. UU No. 33 Tahun 2004: Kewenangan Pemerintah (Pusat) dan Kewenangan Provinsi sebagai Daerah Otonom.

c. UU No. 25 Tahun 2000: Program Pembangunan Nasional, PP No. 19 Tahun 2005: Standar Nasional Pendidikan (SNP), Pasal 61 Permendiknas No. 22, 23, 24 Tahun 2006: Standar Isi, SKL dan Implementasinya.

d. Peraturan Pemerintah No. 19 Tahun 2005 tentang Standar Nasional Pendidikan dalam pasal 61 ayat (1) menyatakan bahwa: Pemerintah bersama-sama pemerintah daerah menyelenggarakan sekurang-kurangnya satu sekolah pada jenjang pendidikan dasar dan sekurang-kurangnya satu sekolah pada jenjang pendidikan menengah untuk dikembangkan menjadi sekolah beratraf internasional.

e. Peraturan Pemerintah No. 38 Tahun 2007 tentang Pembagian Urusan Pemerintah antara Pemerintah, Pemerintah Daerah Provinsi dan Pemerintah Daerah Kabupaten/Kota.

f. Peraturan Pemerintah No. 17 Tahun 2010 tentang Pengelolaan dan Penyelenggaraan Pendidikan.

g. Permendiknas No. 63 Tahun 2009 tentang Penjaminan Mutu Pendidikan.

h. Permendiknas No. 78 Tahun 2009 tentang Penyelenggaraan SBI pada jenjang Pendidikan Dasar dan Menengah.

2. Tujuan Program RSBI

a. Umum

1) Meningkatkan kualitas pendidikan nasional sesuai dengan amanat Tujuan Nasional dalam Pembukaan UUD 1945, pasal 31 UUD 1945, UU No. 20 tahun 2003 tentang SISDIKNAS, PP No.19 tahun 2005 tentang SNP (Standar Nasional Pendidikan), dan UU No.17 tahun 2007 tentang Rencana Pembangunan Jangka Panjang Nasional yang menetapkan Tahapan Skala Prioritas Utama dalam Rencana Pembangunan Jangka Menengah ke-1 tahun 2005-2009 untuk meningkatkan kualitas dan akses masyarakat terhadap pelayanan pendidikan.

2) Memberi peluang pada sekolah yang berpotensi untuk mencapai kualitas bertaraf nasional dan internasional. 
3) Menyiapkan lulusan yang mampu berperan aktif dalam masyarakat global.

b. Khusus

1) Menyiapkan lulusan yang memiliki kompetensi yang tercantum di dalam Standar Kompetensi Lulusan yang diperkaya dengan standar kompetensi lulusan berciri internasional. ${ }^{9}$

3. Karakteristik RSBI

Meskipun RSBI diproyeksikan sebagai sekolah berstandar internasional, RSBI/SBI tetap memiliki karakter khas Indonesia. Sebab RSBI adalah sekolah yang berbudaya Indonesia. Semua bentuk kurikulum, indikator kerja dan pelaksanaan pembelajarannya adalah sebuah design yang akan diwujudkan untuk menghasilkan produk unggulan dari anak-anak bangsa.

Sebagaimana SSN (Sekolah Standar Nasional), karakteristik sekolah yang dikategorikan SBI memiliki kriteria khusus dan umum yang tentu saja mengacu pada standar input, proses, dan output-nya. Salah satu karakteristiknya adalah penerapan kurikulum internasional. Sekolah diwajibkan menggunakan salah satu dari kurikulum internasional, misalnya: Cambridge International Examination, International Bachelorette, Australian Curriculum (Victoria), American Curriculum, dan sebagainya. ${ }^{10}$

Pembeda yang sangat kuat RSBI dengan sekolah-sekolah lain meliputi faktor fisik, intelektual, sosial dan spiritual. Terdapat indikator penting bagi pengembangan sekolah bestandar internasional, yaitu: (1) Memiliki wawasan kebangsaan; (2) Memberdayakan seluruh potensi kecerdasan (multiple intelligence) dan (3) Meningkatkan daya saing global.

Sedangkan pengembangan program kegiatan dan indikator untuk menyusun misi SBI terangkum dalam akronim SMART, yaitu: (1) Specific (spesifik), Measurable (terukur), Achievable (dapat dicapai), Realistic (masuk akal), Time Bound (terikat waktu). ${ }^{11}$

\footnotetext{
${ }^{9}$ Lihat http://www.sekolahinternational.com/2010/10.

10 Lif Khoiru Ahmadi, dkk, Strategi Pembelajaran Sekolah Bertsandar Internasional \&Nasional, (Jakarta: Prestasi Pustakarya, 2010), h. 4-5.

11 Nazaruddin, Manajemen Pembelajaran: ImplementasiKonsep, Karakteristik dan Metodologi Pendidikan Agama Islam di Sekolah Umum, (Yogyakarta: Teras, 2007), h. 62.
} 
Berdasarkan Permendiknas No. 78 Tahun 2009, karaktersitik SBI diantaranya adalah:

a. Proses pembelajaran dalam SBI menerapkan pendekatan pembelajaran berbasis teknologi informasi dan komunikasi, aktif kreatif, efektif, menyenangkan, dan kontekstual.

b. SBI juga dapat menggunakan bahasa pengantar bahasa Inggris dan/atau bahasa asing lainnya yang digunakan dalam forum internasional bagi mata pelajaran tertentu. Pembelajaran bahasa Indonesia, Pendidikan Agama, dan Pendidikan Kewarganegaraan, Pendidikan Sejarah, dan muatan lokal menggunakan pengantar bahasa Inggris atau bahasa asing lainnya tersebut dimulai dari kelas IV untuk SD.

c. SBI menerapkan satuan kredit semester (SKS) untuk SMP, SMA, dan SMK.

d. Peserta didik SBI wajib mengikuti ujian nasional.

e. SBI melaksanakan ujian sekolah yang mengacu pada kurikulum satuan pendidikan yang bersangkutan.

f. SBI dapat melaksanakan ujian sekolah dalam bahasa Inggris atau bahasa asing lainnya.

g. SBI mengembangkan lingkungan sekolah yang bersih, tertib, indah, rindang, aman, sehat, bebas asap rokok dan narkoba, bebas budaya kekerasan, dan berbudaya akhlak mulia. Proses pendidikan berpusat pada pengembangan peserta didik, lingkungan belajar yang kondusif, penekanan pada pebelajaran, profesionalisme, harapan tinggi, keunggulan, respek terhadap setiap individu dan komunitas sosial warga sekolah.

h. SBI mengembangkan budaya kompetitif dan kolaboratif serta jiwa kewirausahaan yang dilandasi oleh moral dan etika yang tinggi.

i. SBI membangun kultur yang mengarah pada peningkatan kemampuan di bidang bahasa Inggris dan/atau bahasa asing lainnya, teknologi informasi dan komunikasi, dan budaya lintas bangsa.

j. Dalam penyelenggaraannya harus bercirikan utama kepada standar manajemen internasional dan meraih ISO versi 2000 atau 
sesudahnya dan ISO14000, dan menjalin hubungan sister school dengan sekolah bertaraf internasional di luar negeri.

k. Jumlah guru minimal20\% berpendidikan S2/S3 dari perguruan tinggi yang program studinya terakreditasi A dan mampu berbahasa Inggris aktif, kepala sekolah minimal berpendidikan S2 dari perguruan tinggi yang proram studinya terakreditasi A dan mampu berbahasa Inggris aktif, serta semua guru mampu menerapkan pembelajaran berbasis TIK.

l. Setiap ruang kelas dilengkapi sarana dan prasarana pembelajaran berbasis TIK, pesrputakaan dilengkapi sarana digital/berbasis TIK, dan memiliki ruang dan fasilitas multimedia.

\section{Visi, Misi, Maksud dan Tujuan RSBI}

Mengacu pada visi pendidikan nasional maka Visi RSBI adalah "terwujudnya insan Indonesia yang cerdas dan kompetitif secara internasional". Sementara misi RSBI adalah mewujudkan manusia Indonesia cerdas dan kompetitif secara nasional terlebih secara internasional yang mampu bersaing dan berkolaborasi secara global.

Sedangkan pembangunan Sekolah/Madrasah Bertaraf Internasional dimaksudkan untuk meningkatkan kemampuan dan daya saing bangsa Indonesia di forum Internasional ${ }^{12}$ Penyelenggaraan SBI bertujuan untuk menghasilkan lulusan yang berkelas nasional dan internasional sekaligus. Lulusan yang berkelas nasional secara jelas telah dirumuskan dalam UU No. 20/2003 dan dijabarkan dalam PP 19/2005, dan lebih rinci lagi dalam Permendiknas No. 23/2006 tentang Standar Kompetensi Lulusan (SKL) yang berbunyi sebagai berikut: Pendidikan menengah pertama bertujuan untuk "meningkatkan kecerdasan, pengetahuan, kepribadian, akhlaq mulia, semua keterampilan untuk hidup mandiri dan mengikuti pendidikan lebih lanjut."

Sekolah bertaraf internasional mengacu pada upaya penguatan, pengayaan, pengembangan, perluasan, pendalaman melalui adaptasi atau

12 Lihat Departemen Pendidikan Nasional, Pedoman Penjaminan Mutu Sekolah/ Madrasah Bertaraf Internasional Pada Jenjang Pendidikan Dasar dan Menengah, Jakarta: Badan Penelitian dan Pengembangan Depdiknas, 2007, h. 2-3 
adopsi terhadap standar pendidikan baik dalam maupun luar negeri, yang diyakini telah memiliki reputasi mutu yang diakui secara internasional. ${ }^{13}$

Gagasan mendirikan sekolah RSB/SBI dengan begitu bukan tanpa sebab, melainkan mempunyai alasan yang bisa diterima oleh akal sehat. Yang melatarbelakangi pendirian sekolah bertaraf internasional ini, menurut Abdurrahman Faridi ${ }^{14}$ selain mengemban amanat UU. No. 20 tahun 2003 adalah adanya misi Depdiknas (sekarang Kemendiknas), untuk mengupayakan peningkatan mutu, efisiensi dan relevansi pendidikan serta kerjasama antar menteri-menteri pendidikan di Asia Tenggara yang tergabung dalam SEAMEO (South East Asian Ministry of Education Organization) dalam meningkatkan kualitas dan persamaan perlakuan (equality).

Paling tidak secara kausalitas dan berurutan penyebab berdirinya RSBI dapat didiskripsikan pada penjelasan berikut:

1. Persaingan global menuntut SDM yang mampu bersaing di tingkat global;

2. Perlu membangun sekolah berkualitas sebagai pusat unggulan (center of excellence) pendidikan sebagai salah satu startegi dalam meningkatkan mutu pendidikan;

3. Melaksanakan amanat UU Sisdiknas No. 20 Tahun 2003 Pasal 50 Ayat 3

4. PP No. 19 tahun 2005 tentang Standar Nasional Pendidikan (SNP), pasal 61 ayat (1).

5. PP No. 17 tahun 2010 tentang Pengelolaan dan Penyelenggaraan Pendidikan.

6. Permendiknas No. 78 tahun 2009 tentang Penyelenggaraan Sekolah Bertaraf Internasional.

Melihat visi misi dan latar belakang pendirian RSBI tentu saja memiliki perbedaan mencolok dengan sekolah pada umumnya. Sebab karakteristiknya lebih diorientasikan pada penguasaan dan pengembangan ilmu pengetahuan global. Peserta didik, di samping terbiasa dengan bahasa Inggris, karena dijadikan sebagai bahasa pengantar, mereka juga tidak asing dengan ICT (Information and Communication Technology). Para guru SBI juga begitu,

\footnotetext{
13 Abdurrahman Faridi, Bahasa Inggris untuk Guru Imersi \& RSBI, (Semarang: Cipta Prima Nusantara, 2009), h. 3.

14 Ibid.
} 
selain dituntut memiliki kelebihan lebih di banding guru sekolah lain, mereka harus berwawasan holistik untuk bisa memenuhi tuntutan yang diharapkan dan menerapkan metode active learning sekaligus melakukan inovasi-inovasi kurikulum agar senantiasa mampu menjawab kebutuhan global.

Sementara itu SBI memiliki instrumental input ideal sebagaimana dijelaskan oleh Slamet Suyanto ${ }^{15}$ seperti berikut: (1) Kurikulum diperkaya (diperkuat, diperdalam, dan diperluas) agar memenuhi standar isi SNP plus kurikulum bertaraf internasional yang digali dari berbagai sekolah dari dalam dan luar negeri yang benar-benar memiliki reputasi internasional; (2) Guru harus memiliki kompetensi profesional (penguasaan mata pelajaran) pedagogik kepribadian dan sosial bertaraf internasional yang ditunjukkan dengan penguasaan salah satu bahasa asing, misalnya bahasa Inggris. Selain itu, guru memiliki kemampuan menggunakan ICT (Information and Communication Technology); (3) Kepala sekolah memiliki kemampuan profesional dalam manajemen kepemimpinan, organisasi, administrasi dan kewirausahaan yang diperlukan untuk menyelengarakan SBI, termasuk kemampuan komunikasi bahasa asing, khususnya bahasa Inggris; (4) Tenaga pendukung, baik jumlah, kualitas maupun kompetensinya memadai untuk menyelenggarakan SBI; (5) Sarana dan prasarana, harus lengkap dan mutakhir untuk mendukung penyelenggaraan SBI, terutama yang terkait langsung dengan penyelenggaraan proses pembelajaran, baik buku, teks, referensi, modul, media belajar, peralatan dan lain sebagainya.

Tidak salah jika dalam buku sistem penyelenggaraan sekolah bertaraf internasional yang diterbitkan oleh Departemen Pendidikan Nasional, dijelaskan bahwa Sekolah Bertaraf Internasional (SBI) dapat dirumuskan sebagai berikut: SBI $=(\mathrm{SNP}+\mathrm{X})$, dimana SNP adalah Standar Nasional Pendidikan (SNP) yang meliputi: kompetensi lulusan, isi, proses, pendidik dan tenaga kependidikan, sarana dan prasarana, dana, pengelolaan, dan penilaian. Sedangkan $\mathrm{X}$ adalah penguatan, pengayaan, pengembangan, perluasan, pendalaman melalui adaptasi atau adopsi terhadap standar pendidikan, baik dari

${ }^{15}$ Slamet Suyanto, "Pengembangan Sekolah Bertaraf Internasional (SBI) Melalui Organisasi Belajar: Konsep dan Implementasi," http://www.apsi-himpsi.org/download-document/3-SBI.php, 12 November 2008, h. 3. 
dalam maupun luar negeri, yang diyakini memiliki reputasi mutu yang telah diakui secara Internasional. ${ }^{16}$

Oleh karena itu, sekolah yang akan melakukan adaptasi ataupun adopsi perlu mencari mitra internasional, misalnya sekolah-sekolah dari negaranegara anggota OECD, yaitu: Australia, Austria, Belgium, Canada, Czech Republic, Denmark, Finland, France, Germany, Greece, Hungry, Iceland, Ireland, Italy, Japan, Korea, Luxembrug, Mexico, Netherlands, New Zealand, Norway, Poland, Portugal, Slovak Republic, Spain, Sweden, Switzerland, Turkey, United Kingdom, United States, dan negara maju lainnya seperti Chile, Estonia, Israel, Russia, Slovenia, Singapore, dan Hongkong yang mutunya telah diakui secara internasional. ${ }^{17}$ Atau bermitra dengan pusat-pusat pelatihan, industry, lembaga-lembaga tes/sertifikasi internasional (seperti Cambridge, IB, TOEFL/TOEIC, dan ISO),pusat-pusat studi dan organisasiorganisasi multilateral (seperti UNESCO, UNICEF, dan SEAMEO), dan sebagainya.

Lebih jelasnya bisa dilihat pada Karakteristik Esensial SMP-SBI sebagai Penjaminan Mutu Pendidikan Bertaraf Internasional sebagai berikut:18

\begin{tabular}{|c|c|c|c|}
\hline No. & $\begin{array}{c}\text { Objek Penjaminan } \\
\text { Mutu (Unsur } \\
\text { Pendidikan dalam } \\
\text { SNP) }\end{array}$ & $\begin{array}{c}\text { Indikator Kinerja } \\
\text { Kunci Minimal } \\
\text { (dalam SNP) }\end{array}$ & $\begin{array}{c}\text { Indikator Kinerja Kunci Tambahan } \\
\text { sebagai (X-nya) }\end{array}$ \\
\hline I & Akreditasi & Berakreditasi A \\
& dari BAN-Sekolah & $\begin{array}{l}\text { Berakreditasi tambahan dari } \\
\text { dan Madrasah }\end{array}$ & $\begin{array}{l}\text { badan akreditasi sekolah pada } \\
\text { salah satu lembaga akreditasi } \\
\text { pada salah satu negara anggota } \\
\text { OECD dan/ atau negara maju } \\
\end{array}$ \\
& & $\begin{array}{l}\text { lainnya yang mempunyai } \\
\text { keunggulan tertentu dalam } \\
\text { bidang pendidikan }\end{array}$ \\
\hline
\end{tabular}

16 Direktorat Jendral Manajemen Pendidikan Dasar dan Menengah, Penyelenggaraan: Rintisan Sekolah Bertaraf Internasinal (SBI) Untuk Sekolah Menengah Pertama (SMP), (Jakarta: Departemen Pendidikan Nasinal, 2006), h. 14-15.

17 Zainal Aqib, Membangun Prestise SSN \& SBI, h. 84-85.

18 Direktorat Jendral Manajemen Pendidikan Dasar dan Menengah, Penyelenggaraan: Rintisan Sekolah Bertaraf Internasinal (SBI) Untuk Sekolah Menengah Pertama (SMP), (Jakarta: Departemen Pendidikan Nasinal, 2006), h. 41-45. 


\begin{tabular}{|c|c|c|c|}
\hline \multirow[t]{3}{*}{ II } & \multirow[t]{3}{*}{$\begin{array}{l}\text { Kurikulum (Standar } \\
\text { Isi) dan Standar } \\
\text { Kompe-tensi } \\
\text { lulusan }\end{array}$} & Menerapkan KTSP & $\begin{array}{l}\text { - Sekolah telah menerapkan sis- } \\
\text { tem administrasi akademik ber- } \\
\text { basis Teknologi Informasi dan } \\
\text { Komunikasi (TIK) dimana setiap } \\
\text { siswa dapat mengakses tran- } \\
\text { skripnya masing-masing. }\end{array}$ \\
\hline & & $\begin{array}{l}\text { Memenuhi } \\
\text { Standar Isi }\end{array}$ & $\begin{array}{l}\text { - Muatan pelajaran (isis) dalam } \\
\text { kurikulum telah setara atau } \\
\text { lebih tinggi dari muatan } \\
\text { pelajaran yang sama pada } \\
\text { sekolah unggul dari salah satu } \\
\text { negara diantara } 30 \text { negara } \\
\text { anggota OECD dan/ atau dari } \\
\text { negara maju lainnya. }\end{array}$ \\
\hline & & Memenuhi SKL & $\begin{array}{l}\text { - Penerapan standar kelulusan } \\
\text { yang setara atau lebih tinggi } \\
\text { dariSNP }\end{array}$ \\
\hline \multirow[t]{2}{*}{ III } & $\begin{array}{l}\text { Proses } \\
\text { Pembelajaran }\end{array}$ & $\begin{array}{l}\text { Memenuhi } \\
\text { Standar Proses }\end{array}$ & $\begin{array}{l}\text { - Proses pembelajaran pada semua } \\
\text { mata pelajaran telah menjadi } \\
\text { teladan atau rujukan bagi sekolah } \\
\text { lainnya dalam pengembangan } \\
\text { akhlak mulia, budi pekerti luhur, } \\
\text { kepribadian unggul, kepemim- } \\
\text { pinan, jiwa kewirausahaan, jiwa } \\
\text { patriot, danjiwa inovator }\end{array}$ \\
\hline & & & $\begin{array}{l}\text { - Proses pembelajaran telah di- } \\
\text { perkaya dengan model-model } \\
\text { proses pembelajaran sekolah } \\
\text { unggul dari salah satu negara } \\
\text { diantara } 30 \text { negara anggota OECD } \\
\text { dan/atau negara maju lainnya. } \\
\text { - Penerapan proses pembel- } \\
\text { ajaran berbasis TIK pada semua } \\
\text { mapel, khususnya pada mapel } \\
\text { IPA, Matematika, dan lainnya } \\
\text { dengan bahasa Inggris, kecuali } \\
\text { mapel bahasa Indonesia. }\end{array}$ \\
\hline IV & Penilaian & $\begin{array}{l}\text { Memenuhi } \\
\text { Standar Penilai-an }\end{array}$ & 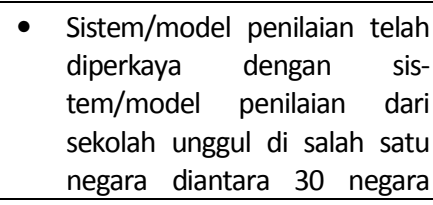 \\
\hline
\end{tabular}




\begin{tabular}{|c|c|c|c|}
\hline & & & $\begin{array}{l}\text { anggota OECD dan/atau } \\
\text { negara maju lainnya. }\end{array}$ \\
\hline V & Pendidik & $\begin{array}{l}\text { Memenuhi } \\
\text { Standar Pendidik }\end{array}$ & $\begin{array}{l}\text { - Guru sains, matematika, dan } \\
\text { teknologi mampu mengajar de- } \\
\text { ngan bahasa Inggris. } \\
\text { - Semua guru mampu memfasilitasi } \\
\text { pembelajaran berbasis TIK. } \\
\text { - Minimal } 20 \% \text { guru berpendidik- } \\
\text { an S2/S3 dari perguruan tinggi } \\
\text { yang program studinya ter- } \\
\text { akreditasi A. }\end{array}$ \\
\hline \multirow[t]{2}{*}{ VI } & $\begin{array}{l}\text { Tenaga } \\
\text { Kependidikan }\end{array}$ & $\begin{array}{l}\text { Memenuhi Stan- } \\
\text { dar Tenaga Kepen- } \\
\text { didikan }\end{array}$ & $\begin{array}{l}\text { - Kepala sekolah berpendidikan } \\
\text { minimal S2 dari perguruan } \\
\text { tinggi yang program studinya } \\
\text { terakreditasi A. } \\
\text { - Kepala sekolah telah me- } \\
\text { nempuh pelatihan kepala } \\
\text { sekolah yang diakui oleh } \\
\text { Pemerintah. } \\
\text { - Kepala sekolah mampu ber- } \\
\text { bahasa Inggris secara aktif. }\end{array}$ \\
\hline & & & $\begin{array}{l}\text { - Kepala sekolah memiliki visi } \\
\text { internasional, mampu mem- } \\
\text { bangun jejaring internasional, } \\
\text { memiliki kompetensi } \\
\text { manajerial, serta jiwa kepe- } \\
\text { mimpinan dan enterprenual } \\
\text { yang kuat. }\end{array}$ \\
\hline VII & Sarana Prasarana & $\begin{array}{l}\text { Memenuhi } \\
\text { Standar Sarana } \\
\text { Prasarana }\end{array}$ & $\begin{array}{l}\text { - Setiap ruang kelas dilengkapi } \\
\text { sarana pembelajaran berbasis TIK. } \\
\text { - Sarana perpustakaan telah dileng- } \\
\text { kapi dengan sarana digital yang } \\
\text { memberikan akses ke sumber } \\
\text { pembelajaran berbasis TIK di se- } \\
\text { luruh dunia. } \\
\text { - Dilengkapi dengan ruang multi- } \\
\text { media, ruang unjuk seni budaya, } \\
\text { fasilitas olah raga, klinik, dan lain- } \\
\text { lain. }\end{array}$ \\
\hline $\begin{array}{c}\text { VII } \\
\text { I }\end{array}$ & Pengelolaan & $\begin{array}{l}\text { Memenuhi } \\
\text { Standar } \\
\text { Pengelolaan }\end{array}$ & $\begin{array}{l}\text { - Sekolah meraih sertifikat ISO } \\
9001 \text { versi } 2000 \text { atau sesudah- } \\
\text { nya (2001, dst) dan ISO } 14000\end{array}$ \\
\hline
\end{tabular}




\begin{tabular}{|c|c|c|c|}
\hline & & & $\begin{array}{l}\text { - Merupakan sekolah multi- } \\
\text { kultural } \\
\text { - Sekolah telah menjalin hubung- } \\
\text { an "sister school" dengan se- } \\
\text { kolah bertaraf/ berstandar inter- } \\
\text { nasional di luar negeri } \\
\text { - Sekolah terbebas dari rokok, } \\
\text { narkoba, kekerasan, kriminal, } \\
\text { pelecehan seksual, dan lain-lain } \\
\text { - Sekolah menerapkan prinsip ke- } \\
\text { setaraan gender dalam semua } \\
\text { aspek pengelolan sekolah }\end{array}$ \\
\hline IX & Pembiayaan & $\begin{array}{l}\text { Memenuhi Stan- } \\
\text { dar Pembiayaan }\end{array}$ & $\begin{array}{l}\text { - Menerapkan model pembiaya- } \\
\text { an yang efisien untuk mencapai } \\
\text { berbagai target indikator kunci } \\
\text { tambahan }\end{array}$ \\
\hline
\end{tabular}

Begitulah syarat-syarat yang harus dipenuhi oleh sekolah yang ingin meningkatkan statusnya menjadi RSBI/SBI. Melihat penjaminan SBI di atas, dapatlah dikatakan sesungguhnya parameter tersebut bukanlah suatu mainmain tetapi sebuah indikator ketat bagi sekolah bertaraf internasional. Sekolah yang menyandang status RSBI/SBI, harus memiliki nilai lebih dari sekolah reguler. Dari aspek legalitasnya, selain terakreditasi A harus terakreditasi tambahan dari badan akreditasi sekolah pada salah satu lembaga akreditasi pada salah satu negara anggota OECD dan/atau negara maju lainnya yang mempunyai keunggulan tertentu dalam bidang pendidikan. Serta, memiliki indikator kinerja minimal yang lain seperti yang terdapat dalam SNP ditambah dengan indikator kinerja tambahan (x), sebagaimana penjelasan di atas .

\section{Memproduk Lulusan Berkualifikasi Internasional}

Indonesia sebagai negara berkembang mutlak mengejar ketertinggalannya dengan negara-negara lain. Karena dalam realitasnya, SDM negara kita masih rendah bila dibanding dengan negara tetangga seperti Jepang, China, India, Korea Selatan, Malaysia, Singapura dan Thailand. Apalagi dengan negara Amerika Serikat, Inggris, Prancis, Australia, Jerman, dannegara maju lainnya. Letak kesalahan yang segera harus dievaluasi adalah pendidikan kita belum mempersiapkan tenaga yang terampil dan siap pakai. Bukankah 
banyak keluhan dari stakeholders, bahwa lulusan dari sekolah kita belum teruji dan memiliki sertifikasi internasional? Padahal, dengan diberlakukannya AFTA dan perdagangan bebas sebagai akibat globalisasi, Indonesia saat ini menghadapi ancaman dari adanya luberan tenaga kerja asing yang mempunyai kualifikasi sesuai dengan kebutuhan kompetensi kerja yang disyaratkan pasaran tenaga kerja. Wajar jika para lulusan dari sekolah kita, semakin tidak terserap di pasar kerja.

Seringnya keluhan dari industri biasanya lulusaan dari sekolah belum mempunyai kompetensi how to do. Oleh karenanya secara mandiri semua perusahaan menerima lulusan dari sekolah secara apa adanya, kemudian dilakukan pembinaan. Kurikulum dan silabus pembinaan diturunkan dari kompetensi, yang dapat dikelompokkkan menjadi: ${ }^{19}$ ilmu terapan, konsepkonsep kerja operasional, dan praktek kerja yang merealisir konsep kerja tersebut menjadi tindakan nyata yang dapat diukur keberhasilanya. Implikasinya, karena biaya pembinaan yang harus dikeluarkan perusahaan besar biasanya lebih melirik pada lulusan yang siap pakai.

Merespon kenyataan rendahnya SDM kita dan tidak memenuhi standar pasar, tak salah jika pemerintah kita senantiasa mencari alternatif lain dalam menjawab tantangan seperti tersebut, salah satunya adalah membuka sekolah RSBI/SBI. Harapanya tentu saja mempersiapkan para lulusan yang memiliki kualifikasi internasional, selain terampil mereka juga siap berkompetisi secara global. Lulusan dengan kualifikasi demikian, diyakini banyak pihak mampu mempersiapkan masyarakat yang independen, mudah diberdayakan dan incremental. Output pendidikannya, bukan menjadi masyarakat pencari kerja (worker society) tetapi siap menjadi masyarakat pencipta lapangan kerja (employee society) atau masyarakat pewirausaha (enterpreneurship society). Sementara untuk merealisasikan tujuan mulia ini, tentu saja menerapkan sistem pendidikan yang berbeda dengan sistem pendidikan yang selama ini berlangsung. Sistem tersebut menerapkan Quality Management dalam penerapan ISO 9001 atau menerapkan Total Quality Management (TQM).

${ }^{19}$ Mustakim, "Desain PerguruanTinggi Berorientasi Kompetensi Lulusan dan Esensi Sertifikat Internasional dalam Bidang Pendidikan," dalam Andi Haris Prabwa, dkk., Paradigma Pengembangan Kurikulum, h. 56. 


\section{E. Manajemen Mutu Terpadu (TQM)}

Hakikat TQM (Total Quality Management) adalah filosofi dan budaya kerja organisasi (philosophy of management) yang fokus pada kualitas. Tujuan (goal) yang ingin dicapai dalam organisasi dengan budaya (culture) TQM adalah memenuhi atau bahkan melebihi apa yang dibutuhkan (needs) dan diharapkan atau diinginkan (desires) oleh pelanggan. Menurut Edward Sallis, ${ }^{20}$ sebagai sebuah pendekatan praktis dan strategis TQM bertujuan untuk mencari hasil yang lebih baik.
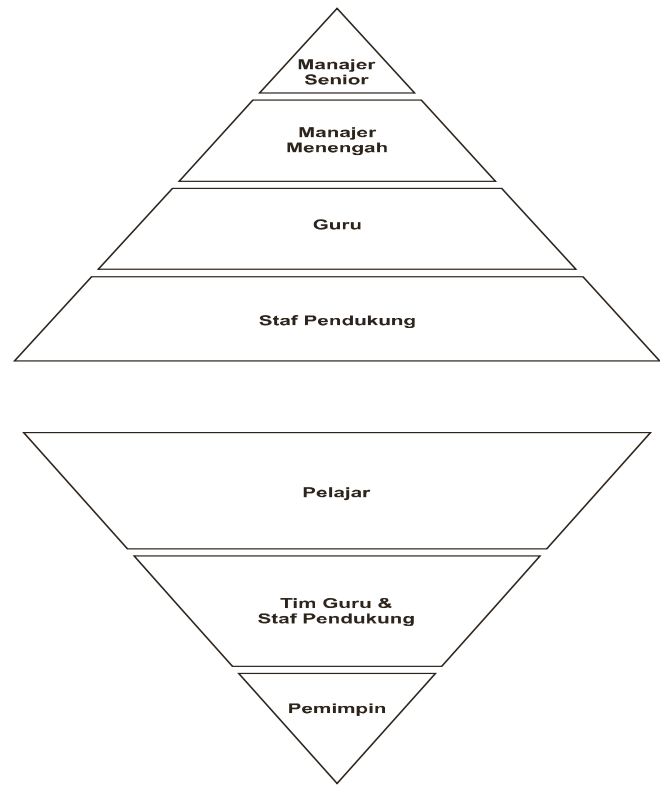

Gambar 1.

TQM dalam Pendidikan (Institusi Terbalik) ${ }^{21}$

Pelaksanaan sekolah dengan quality management adalah suatu pelaksanaan fungsi manajemen untuk mencapai kebijakan mutu organisasi dan mengimplementasikan dalam quality planning, quality control, quality

\footnotetext{
${ }^{21}$ Lihat dan bandingkan gambar institusi hirarkis dan intitusi terbalik dalam pendidikan dalam Edward Sallis, ibid., h. 81.
} 2010), h. 76 .

${ }^{20}$ Edward Sallis, Total Quality Management dalam Konteks Pendidikan, (Yogyakarta: IRCiSoD, 
assurance, quality improvement dalam suatu quality systems. Dimana Quality systems adalah struktur organisasi, pertanggungjawaban, prosedur, proses maupun sumberdaya yang digunakan untuk mengimplementasikan manajemen mutu dengan tujuan untuk memberikan jaminan kepada stakeholder bahwa kualitas selalu konsisten memenuhi syarat yang dikehendaki oleh pemakai jasa. Sehingga sekolah yang sudah menerapkan TQM, bisa dipastikan memiliki tingkat kualitas lulusanya yang sangat baik dan tidak mengecewakan pelanggan.

Sebab, tujuan akhir penerapan manajemen mutu terpadu (TQM) dalam pendidikan adalah meningkatkan kualitas, daya saing bagi output dengan indikator adanya kompetensi, baik intelektual maupun skill, serta kompetensi sosial lulusan yang tinggi. Tak salah jika untuk memenuhi harapan ini, TQM menerapkan organisasi terbalik, dimana lebih ditekankan pada pola hubungan yang berorientasi pada pemberian layanan dan pentingnya pelanggan bagi institusi.

Memang untuk menerapkan TQM, banyak hambatan yang harus dihadapi oleh sekolah diantaranya: budaya kerja, unjuk kerja, dan disiplin dari pelaksana sekolah (guru, karyawan, dan kepala sekolah).

Terdapat delapan prinsip yang harus diterjemahkan dalam tataran praktis manajerial sekolah dalam rangka memanej pola organisasi demi meningkatkan mutu pendidikan, yaitu: fokus pada pelanggan (peserta didik), kepemimpinan, pelibatan anggota, pendekatan proses, pendekatan sistem pada manajemen, perbaikan berkesinambungan. ${ }^{22}$

Secara skematis, diagram perbaikan berkesinambungan mutu pendidikan dapat dilihat pada gambar pada halaman berikut.

Prinsip perbaikan secara terus menerus di atas dalam penerapan TQM di lembaga pendidikan harus senantiasa dilakukan, meskipun dengan step by step improvement sehingga menimbulkan dampak bagi kesadaran bagi setiap komponen di dalamnya untuk menganalisa setiap bentuk problematika yang dihadapi dan merencanakan perbaikanya. h. $153-154$

22 Umi Arso \& Imam Gojali, Manajemen Mutu Sekolah di Era Otda, (Yogyakarta: Ircisod, 2010), 


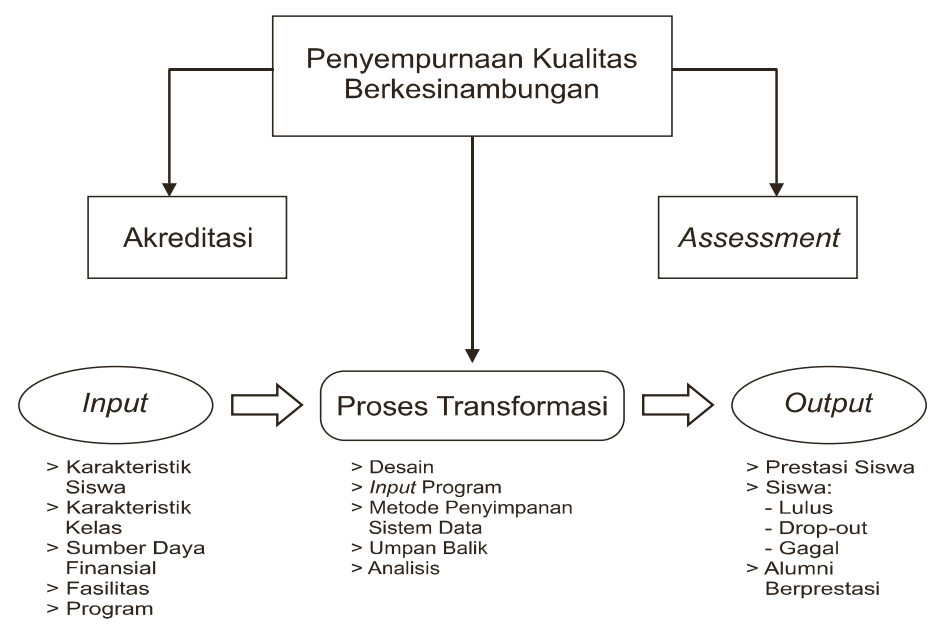

\section{Gambar 2.}

Diagram Perbaikan Berkesinambungan Mutu Pendidikan

\section{F. Pembelajaran Berbasis TIK}

Munculnya berbagai perubahan yang sangat cepat di hampir semua lini kehidupan, dan telah menggeser paradigma lama menjadi paradigma baru. Seiring dengan itu pula, pendidikan mencoba merespon setiap perubahan yang terjadi. Dengan maksud, agar kualitas yang dihasilkan pendidikan tidak lagi dinilai kadaluwarsa dan tidak peka terhadap perkembangan jaman. Dengan itu pendidikan melakukan perubahan-perubahan di beberapa hal. Diantaranya telah dikembangkannya kurikulum baru dan dikembangkannya berbagai metode dan model pendidikan terbaru.

Upaya mencerdaskan kehidupan bangsa dan mengembangkan kualitas manusia seutuhnya, adalah misi pendidikan yang menjadi tanggung jawab profesional setiap guru. Guru tidak cukup hanya menyampaikan materi pengetahuan kepada siswa di kelas tetapi dituntut untuk meningkatkan kemampuan guna mendapatkan dan mengelola informasi yang sesuai dengan kebutuhan profesinya. Mengajar bukan lagi usaha untuk menyampaikan ilmu pengetahuan, melainkan juga usaha menciptakan sistem lingkungan yang membelajarkan subjek didik agar tujuan pengajaran dapat tercapai 
secara optimal. Termasuk dalam hal ini adalah memperkenalkan ICT kepada peserta didik, sehingga mereka tidak lagi ketinggalan dengan perkembangan informasi dan teknologi yang sudah menjadi kenyataan abad modern sekarang.

Mengajar dalam pemahaman ini memerlukan suatu strategi belajar mengajar yang sesuai. Mutu pengajaran tergantung pada pemilihan strategi yang tepat dalam upaya mengembangkan kreativitas dan sikap inovatif subjek didik. Untuk itu perlu dibina dan dikembangkan kemampuan profesional guru untuk mengelola program pengajaran dengan strategi belajar yang kaya dengan variasi. Dari situ terlihat jelas bahwa untuk mencapai tujuan yang optimal diperlukan suatu perancangan yang baik sebagai pendukung suasana belajar yang diinginkan. Dalam hal ini strategi yang baik juga sangat menentukan untuk pencapaian tujuan yang ditetapkan.

Strategi pembelajaran merupakan langkah-langkah untuk penentuan dan pengurutan kondisi dalam kegiatan pembelajaran. Strategi pembelajaran berinteraksi dengan situasi belajar. Strategi pembelajaran merupakan suatu pendekatan dalam mengorganisasikan komponen-komponen pembelajaran yang dibutuhkan untuk mencapai tujuan pembelajaran.

Telah maklum, bahwa RSBI/SBI merupakan sekolah yang bertujuan untuk mempersipakan peserta didiknya memiliki kemampuan bersaing di tingkat internasional. Dengan demikian, tak pelak lagi, strategi pembelajarannya harus mengantarkan peserta didik bisa berinteraksi dan bergaul dengan dunia global. Selain bahasa inggris sebagai bahasa komunikasi yang harus dikuasasi, mereka harus juga diperkenalkan dengan berbagai strategi pembelajaran berbasis TIK. Sehingga, para seserta didiknya mampu berkomunikasi secara eloktronik, seperti; dapat mengoperasikan komputer, menggunakan internet dan menguasai teknologi informatika lainnya.

Hal tersebut mengingat memasuki era dunia pendidikan yang baru sekarang, pendidikan tidak hanya sebagai proses pemanusiaan manusia yang dilaksanakan secara biasa. Saat ini sekolah-sekolah sekarang, apalagi RSBI harus mencoba menerapkan unsur-unsur teknologi informasi dan komunikasi dalam pelaksanaan pendidikannya, baik dalam segi pembelajaran maupun dalam segi managemen pendidikan di sekolah tersebut. Beberapa Komponen utama sekolah berbasis TIK setidaknya terdiri dari: (1) konten dan kurikulum; (2) proses pembelajaran; (3) sarana dan prasarana; (4) kom- 
petensi SDM sekolah; (5) sistem administrasi dan manajemen sekolah; (6) infrastruktur dan suprastruktur.

Strategi pembelajaran yang baik adalah strategi yang mampu mengkondisikan segala aspek perbedaan peserta didik baik yang menyangkut kecerdasan, perbedaan individu, latar belakang, kemampuan dan segala aspek yang ada pada anak didik. Dewasa ini di persekolahan kemampuan otak siswa kadang kurang diperhatikan padahal kemampuan otak manusia adalah tidak terbatas. Namun banyak orang yang tidak mampu mengolahnya sampai kepada penggunaan yang optimal, sehingga hasil yang dicapai juga kurang maksimal. Hal ini disebabkan karena strategi pembelajaran yang digunakan dalam proses pembelajaran kurang merangsang kepada penggunaan otak secara keseluruhan. Oleh sebab itu, dalam konten dan kurikulum harus menekankan pada pendidikan yang lebih bermakna. Sehingga dunia anak bukanlah dunia guru, dalam prespektif ini, anak dituntut kreatif dan eksploratif secara mandiri sehingga mampu ikut memberikan kontribusi bagi bangsanya.

Dalam rangka terbentuknya sekolah yang unggul dan berkualitas internasional, sekolah RSBI harus memiliki jaringan nasional maupun regional/ internasional, maka sekolah yang dipilih harus melengkapi dirinya dengan berbagai fasilitas sarana dan prasarana baik ruang kelas, laboratorium, perpustakaan, buku pelajaran, peralatan peraga pendidikan, serta sarana informasi, komunikasi, dan teknologi seperti komputer dan fasilitas internet. Fasilitas TIK selain sebagai media komunikasi juga merupakan sarana bagi warga sekolah untuk meningkatkan pengetahuan atau wawasannya. Melalui internet setiap siswa dapat memperoleh berbagai informasi atau bahan pembelajaran yang mutakhir. Dengan fasilitas TIK, RSBI akan dapat mengembangkan program-program kerjasamanya, termasuk saling tukar gagasan inovasi pembelajaran dan materi pembelajaran, baik di dalam negeri dan luar negeri .

Kenyataan di lapangan menunjukkan bahwa, banyak siswa di Negara kita yang sebenarnya memiliki kecerdasan yang tinggi namun tidak dapat diberdayakan sebaik mungkin, sehingga dalam belajar ia tidak mencapai hasil belajar yang baik. Ada anak yang memiliki kecerdasan tinggi namun karena strategi pembelajaran yang kurang sesuai dengan perkembangannya menjadikan pebelajar tersebut berada di tingkat bawah. Namun sebaliknya ada 
anak yang memiliki kecerdasan menengah dapat berhasil dalam pembelajaran karena strategi pembelajaran yang digunakan sesuai dengan kebutuhannya.

Memang harus diakui bahwa realitas pola pendidikan Indonesia yang selama ini dipakai masih cenderung mematikan kreativitas dan memenjarakan peserta didik. Pendidikan hanya menuntut peserta didik untuk "selalu patuh" dan tidak memberikan kebebasan sedikitpun kepadanya untuk bersikap kritis dan rasional. Pendidikan kita terlanjur menekankan titik berat kepada "penimbunan fakta-fakta" melupakan "belajar berfikir". Karena pendidikan selalu ditekankan pada pemikiran konvergen dan terlalu dibiasakan untuk berfikir secara tertib dan dihalangi kemungkinanya untuk merespon dan memecahkan masalah secara bebas. Akibatnya adalah stagnasi yang menjurus ke keadaan statis dan akhirnya macet dalam berfikir dan bertindak.

Mengatasi hal tersebut, maka diperlukan adanya era reformasi disegala bidang termasuk di dalamnya pendidikan sebagai faktor utama dalam mencerdasakan kehidupan bangsa. Dan saat ini dalam dunia pendidikan telah mengalami banyak pembenahan dan penyegaran. Sebagai bukti adalah lahirnya Kurikulum dan model maupun metode baru yang berbeda dari metode dan model lama. Sebab, model dan metode baru ini lebih menekankan pada peran dan aktivitas peserta didik ketimbang dominasi guru di dalam kelas. Termasuk dalam kategori model terbaru ini adalah menggunakan strategi pembelajaran berbasis TIK, selain memiliki banyak manfaat sebagaimana penjelasan di atas menjadikan pembelajaran semakin hidup, menantang dan mengasikkan bagi peserta didik.

\section{G. Problematika RSBI}

Beragam perubahan dan perbaikan sistem pendidikan di Negara kita, meskipun belum menunjukkan keberhasilan perlu kita apresiasi sebagai wujud nyata kesadaran pemerintah untuk menyediakan pendidikan yang bermutu bagi bangsanya. Hal ini bisa dibuktikan lahirnya Undang-Undang No 20 tahun 2003 tentang sistem pendidikan nasional dan jaminan terselenggaranya pendidikan bermutu yang didasarkan pada Peraturan Pemerintah No. 19 tahun 2005 tentang Standar Nasional Pendidikan. Lebih-lebih dalam Bab XIV pasal 50 ayat 3 Undang-Undang No. 20 Tahun 2003 tentang Sistem Pendidikan Nasional, disebutkan bahwa: 
"Pemerintah dan/atau pemerintah daerah menyelenggarakan sekurangkurangnya satu-satuan pendidikan pada semua jenjang pendidikan, untuk dikembangkan menjadi satuan pendidikan yang bertaraf internasional."

Menuju pendidikan berkualitas di tingkat internasional tersebut tidak boleh dipandang remeh, mengingat Indonesia merupakan bagian dari kehidupan dunia yang mengglobal, maka selaras dengan tuntutan global perlu dipikirkan agar mempunyai pendidikan yang terakreditasi internasional. Dimana mutu lembaga pendidikan kita diakui secara internasional. Pendidikan Indonesia tidak perlu "malu hati" apalagi bersikap arogan dalam menghadapi kriteria yang digunakan pada tingkat internasional. ${ }^{23}$ Relevan dengan ini, Prof. Djohar, mengingatkan bahwa untuk mencapai tingkat akreditasi internasional, maka fokus pendidikan kita adalah lebih diarahkan kepada optimalnya praksis pendidikan dalam tataran klinik pendidikan, sehingga klinik pendidikan kita menjadi realistik, dan dengan upaya itu apabila akareditasi internasional pendidikan kita meningkat itu adalah sebagai akibat.24

Oleh sebab itu, perlu dimaklumi jika sekarang sekolah-sekolah kita ramerame mempersipakan diri dan bermetamorfosis menjadi sekolah bertaraf internasional dengan segala keterbatasanya. Masyarakatpun akhirnya disuguhi beragam lembaga pendidikan dengan label-label; mulai dengan Sekolah Berstandar Nasional, menuju RSBI dan SBI. Alasan menuju sekolah SBI ini bisa diterima, mengingat manajemen bisnis saja dikelola dengan istilah International Standard Organization (ISO), apalagi di bidang pendidikan. Maka, dengan standar internasional ini diharapkan dapat mengetahui kualitas penyelenggaraan pendidikan dimana pun berada.

Meskipun sekolah dengan label SBI pada perjalanan sistem pendidikan di Indonesia mengalami banyak tantangan, karena tidak seperti pada awal tujuan didirikannya. Selain pelabelan SBI, menimbulkan kecemburuan dengan sekolah-sekolah lain, label tersebut belum mencerminkan peningkatan kualitas yang diharapkan. Bahkan sekolah SBI, terkesan eksklusif dan tidak terjangkau bagi masyarakat miskin. Padahal sesuai amanat PP No. 66 sekolah berstatus RSBI harus menyediakan 20\% kursi bagi siswa tidak mampu. 157.

${ }^{23}$ Aulia Reza Bastian, Reformasi Pendidikan, (Yogyakarta: Lappera Pustaka Utama, 2002), h.

${ }^{24} \mathrm{Ibid}$, h. 159-160. 
Secara konsep, RSBI mungkin dianggap sebagai sekolah yang ideal karena bisa "mengglobal dan bergengsi". Sekolah ini dipersiapkan secara khusus untuk mewakili dalam beberapa pertanyaan akan tingginya kualitas pendidikan yang ada di negeri ini. Sebab, sekolah RSBI ini dituntut memiliki beberapa pesryaratan yang dibilang tidak mudah. Di samping harus menuntaskan kurikulum nasional, RSBI juga memiliki kewajiban dengan ditambahkannya kurikulum internasional. Seperti penggunaan fasilitas belajar berbasis teknologi informasi, kelengkapan sarana dan prasarana, seperti ruangan ber-AC, dan tentunya bahasa Inggris sebagai bahasa pengantar.

Seluruh fasilitas yang serba plus-plus tentu saja harus ditebus dengan harga yang mahal. Untuk mengadopsi dan mengembangkan kurikulum Cambridge, misalnya, ada yang dinamakan commitment fee. Sekolah harus membayar sekitar 24 juta rupiah per tahun dan selalu berubah sesuai dengan fluktuasi mata uang internasional. Atau, untuk mengikuti ujian mendapatkan sertifikat Cambridge, satu mata pelajaran dikenai biaya satu juta rupiah. Belum lagi terkait dengan kerja sama pembinaan dan pendampingan dalam rangka peningkatan kualitas manajemen sumber daya manusia.

Melihat beban berat menjadi sekolah RSBI tersebut, wajar jika banyak sekolah dibeberapa daerah yang terkesan asal-asalan menerapkan standar RSBI hanya demi sebuah gengsi dan supaya bisa mengangkat derajat sekolah dimata masyarakat. Karena pada kenyataannya sekolah dengan label RSBI banyak dilirik dan diminati oleh para orang tua peserta didik. Mungkin karena dianggap memiliki mutu yang lebih baik dibanding dengan sekolah biasa.

Padahal 88,8\% sekolah di Indonesia, mulai SD hingga SMA/ SMK, belum melewati mutu standar pelayanan minimal. Berdasarkan data yang ada, 40,31\% dari 201.557 sekolah di Indonesia di bawah standar pelayanan minimal, dan hanya $10,15 \%$ yang memenuhi standar nasional pendidikan. Dengan keadaan itu, pemerintah gencar menggelontorkan dana menciptakan rintisan sekolah bertaraf internasional: 0,65\%.25 Ini artinya label RSBI, dengan standar yang harus dipenuhi oleh sejumlah sekolah yang merubah status RSBI harus dipertanyakan oleh semua pihak.

Selain pendekatan proses belajarnya yang tidak sesuai, masih ada tenaga pengajar yang tidak sesuai dengan kualitas internasional, banyak guru yang belum lulusan program magister (S.2), padahal ini merupakan syarat yang

25 Lihat Kompas, 31 Maret 2011. 
harus dipenuhi RSBI. Begitu pula dalam fasilitas yang diberikan masih belum optimal. Masih ada guru yang tidak memiliki kemampuan bahasa Inggris mumpuni, bahkan terkadang kemampuan bahasa inggris "si murid" jauh lebih mumpuni dari gurunya. Akibatnya hasil dari kegiatan belajar mengajarnya pun tidak optimal.

Efek dari semua masalah tersebut, pemerintah telah mengevaluasi proses sekolah tersebut dan belum berani menyebut dengan Sekolah Bertaraf Internasional (SBI), melainkan RSBI serta pemerintah kita sedang menyiapkan aturan baru soal standar SBI. Hal ini sebagaimana pernyataan Fasli Jalal, ${ }^{26}$ Wakil Menteri Pendidikan Nasional Fasli Jalal, dalam acara "Simposium Sistem RSBI/SBI: Kebijakan dan Pelaksanaan" yang dilaksanakan British Council di Jakarta, Rabu (9/3/2011), seperti berikut: "Ternyata sekolah bertaraf internasional tidak sederhana. Ini perjalanan panjang yang wajahnya sampai sekarang belum jelas. Karena itu, kami belum berani menyebut sekolah bertaraf internasional (SBI), tetapi masih rintisan SBI. Untuk itu, pemerintah menahan dulu pemberian izin baru RSBI".

Semantara itu, Mansyur Ramly, ${ }^{27}$ Badan Penelitian dan Pengembangan (Balitbang) Kemdiknas menyatakan bahwa dalam dua bulan akan dilakukan perubahan standar RSBI. Perubahan tersebut. Pertama, menyangkut substansi, yaitu peraturan perundang-undangan, istilah-istilah konsep, dan sebagainya. "Contoh perubahan istilah di antaranya mengenai apa itu RSBI. Di Peraturan Pemerintah No. 17 sudah disebutkan merupakan sekolah dengan standar pendidikan negara maju," katanya. Kedua, adalah mengenai kewajibannya. "Kami akan pertajam imperasinya. Misalnya di dalam aturannya pemerintah menjamin terselenggaranya pendidikan dasar tanpa dipungut biaya.

Ia mengakui jika biaya sekolah semakin lama semakin mahal. Meskipun demikian tidak ada alasan bagi para RSBI untuk menaikkan biaya untuk para siswa. "SD dan SMP yang termasuk golongan RSBI tidak boleh memungut biaya apapun dari siswa. Jika ada tambahan biaya maka hal itu harus dibebankan kepada pemda setempat.

Dalam evaluasi yang akan dilakukan terhadap RSBI, terdapat konsep yang ditawarkan diantaranya; pertama rekrutmen siswa harus didasarkan

\footnotetext{
${ }^{26}$ Lihat http://edukasi.kompas.com. Diakses pada hari rabu, 8 Juni 2011.

${ }^{27}$ Lihathttp://www.republika.co.id, diakses pada hari Rabu, 8 Juni 2011.
} 
pada kemampuan akademik siswa. RSBI harus bisa menunjukkan bahwa mutunya dari sisi akademik lebih baik dari yang biasa. Kedua adalah aspek finansial, dimana RSBI harus seminimal mungkin mengadakan pungutan. Sekolah harus membuat anggaran belanja dulu. Maksimal mereka hanya bisa memungut maksimal sekitar 20\% dari persentase belanja sekolah. Ketiga, adalah tata pengelolaan yang transparan. Seandainya terdapat pungutan maka hal tersebut harus dibuka untuk apa. Pungutan tersebut hanya boleh diperuntukkan untuk proses belajar-mengajar.

\section{H. Kasus RSBI SMP 2 Semarang}

Menuju pendidikan berkualitas di tingkat internasional tersebut tidak boleh dipandang remeh, mengingat Indonesia merupakan bagian dari kehidupan dunia yang mengglobal, maka selaras dengan tuntutan global perlu dipikirkan agar mempunyai pendidikan yang terakreditasi internasional. Dimana mutu lembaga pendidikan kita diakui secara internasional. Pendidikan Indonesia tidak perlu "malu hati" apalagi bersikap arogan dalam menghadapi kriteria yang digunakan pada tingkat internasional.

Agar harapan menuju sekolah dengan sertifikasi internasional dapat terealisir adalah dengan memperbaiki sistem yang ada sebaik mungkin, mencoba mengidentifikasi beberapa kendala yang dihadapi kemudian dicarikan pemecahannya. Relevan dengan persoalan ini, menarik hasil penelitian yang dilakukan pada SMP 2 Semarang ini, dimana perubahan menjadi rintisan sekolah dunia atau memperoleh pengakuan secara internasional menghadapi banyak kendala. Baik itu, Kendala ekonomi, psikologi, budaya kerja, rekrutmen atau seleksi penerimaan siswa, akademik, penetapan biaya, dan tata kelola dalam RSBI.

Pada aspek finansial, dimana RSBI harus seminimal mungkin mengadakan pungutan. Sebab bagaimanapun harus kita akui bahwa, RSBI dari segi penyelenggaraan bertujuan untuk meningkatkan kualitas sumber daya manusia. Namun dalam menetapkan tarif pendidikannya, oleh kebanyakan orang masih dipandang belum sejalan dengan prinsip keadilan dan pemerataan masyarakat dalam memperoleh akses pendidikan yang murah dan berkualitas. Karena biaya pendidikan yang mahal tentu sangat tidak ramah pada kelompok masyarakat miskin. Untuk mengantisipasi persoalan itu, RSBI SMP 2 Semarang biasanya membuat anggaran belanja dulu. Maksimal 
mereka hanya bisa memungut sekitar 20\% dari persentase belanja sekolah. Membuat program subsidi silang bagi orang yang tidak mampu serta untuk bisa menutup kekurangan biaya, RSBI ini perlu kreatif melakukan fund rising dalam bentuk-bentuk kerjasama dengan lembaga-lembaga lain, baik dalam negeri maupun luar negeri.

Meskipun begitu, praktik pembelajaran dalam artian serangkaian proses belajar mengajar yang terdiri dari berbagai komponen belajar baik subjek belajar, objek belajar, strategi, media, alat pembelajaran maupun evaluasi yang berorientasi pada terciptanya tujuan memproduk lulusan yang berwawasan global dan mampu bersaing di tingkat internasional, telah dipersipakan dengan baik di SMP ini. Dengan melihat kenyataan globalisasi, peserta didik dan guru sebagai subjek dalam pembelajaran harus memiliki pandangan yang futuristik dan kreatif.

Rekrutmen siswa yang dilakukan RSBI SMP 2 Semarang didasarkan pada kemampuan akademik siswa. RSBI ini, telah menunjukkan bahwa mutunya dari sisi akademik lebih baik dari yang biasa. Untuk keperluan ini sekolah biasa mensosialisasikannya kepada masyarakat luas bahwa RSBI adalah sekolah yang mengutamakan kualitas dan profesionalitas, maka penyaringan siswa-siswi berprestasi sesungguhnya yang dikedepankan daripada persoalan kekayaan yang dimiliki mereka.

Menariknya kehadiran RSBI SMP 2 Semarang bisa dikatakan telah memainkan peranan sebagai lembaga sekolah yang memiliki peran sebagai konservatif, kreatif dan kritis evaluatif. Peran konservatif, telah menjaga dan mentransmisikan kebudayaan kepada anak didik, terbukti di SMP 2 Semarang ini, selain mengajarkan bahasa Jawa juga menjaga tradisi sebagai masyarakat Jawa dengan mengajarkan kepada peserta didik program Seni Karawitan dan Seni Tari.

Sementara pada peran kreatif dan kritis, RSBI di SMP 2 bisa dilihat dengan menganalisis kurikulum yang diterapkan telah mendesain kurikulum pendidikanya berdasarkan unsur-unsur lapisan sosial, pengelompokan sosial, sistem kelembagaan sosial dan norma-norma yang sudah melembaga di dalam kehidupan masyarakat. Dan evaluatif, memainkan peran sebagai kontrol sosial dan menekankan pada unsur-unsur berfikir kritis dimana nilainilai sosial yang tidak sesuai dengan perkembangan teknologi disisihkan dan yang sesuai ditata untuk disiapkan menjadi bentuk pengalaman belajar. 


\section{Kesimpulan}

Gagasan mendirikan sekolah RSB/SBI dengan begitu bukan tanpa sebab, melainkan mempunyai alasan yang bisa diterima oleh akal sehat. Yang melatarbelakangi pendirian sekolah bertaraf internasional ini, selain mengemban amanat UU No. 20 tahun 2003 adalah adanya misi Depdiknas (sekarang Kemendiknas), untuk mengupayakan peningkatan mutu, efisiensi dan relevansi pendidikan serta kerjasama antar menteri-menteri pendidikan di Asia Tenggara yang tergabung dalam SEAMEO (South East Asian Ministry of Education Organization) dalam meningkatkan kualitas dan persamaan perlakuan (equality).

Tujuan mulia RSBI tersebut, dalam realisasinya seharusnya jangan dicemari dengan motif-motif yang tidak "humanis" dan terkesan bertolak belakang dengan visi misi RSBI. Penyelenggaraan sekolah internasional, yang selama ini terkesan hanya membidik masyarakat yang selalu menganggap "wah" dengan sesuatu yang berlabel internasional-perlu menjadi "sekolah rakyat" dan dekat dengan orang-orang miskin, tentu dengan proporsi seimbang antara kaya-miskin dan tergantung kualitas. Pemerintah daerah juga jangan merasa silau dan over convidence dengan label-label internasional, tapi harus berimbang dengan menekankan keadilan bagi terselenggaranya seluruh pendidikan yang ada.[w] 


\section{BIBLIOGRAFI}

Ahmadi, Lif Khoiru, dkk., Strategi Pembelajaran Sekolah Bertsandar Internasional \& Nasional, Jakarta: Prestasi Pustakarya, 2010.

Aqib, Zainal, Membangun Prestise SSN \& SBI, Bandung: Yrama Widya, 2010.

Arso, Umi \& Gojali, Imam, Manajemen Mutu Sekolah di Era Otda, Yogyakarta: Ircisod, 2010.

Asmani, Jamal Ma'mur, Tips Efektif Menjadi Sekolah Berstandar Nasional \& Internasional, Yogyakarta: Harmoni, 2006.

Departemen Pendidikan Nasional, Pedoman Penjamin Mutu Sekolah/ Madrasah Bertaraf Internasional pada Jenjang Pendidikan Dasar dan Menengah, Jakarta: Badan Penelitian dan Pengembangan Departemen Pendidikan Nasional, 2007.

Direktorat Jendral Manajemen Pendidikan Dasar dan Menengah, Penyelenggaraan: Rintisan Sekolah Bertaraf Internasinal (SBI) Untuk Sekolah Menengah Pertama (SMP), Jakarta: Departemen Pendidikan Nasinal, 2006.

Faridi, Abdurrahman, Bahasa Inggris untuk Guru Imersi \& RSBI, Semarang: Cipta Prima Nusantara, 2009.

http://www.sekolahinternational.com/2010/10, diakses pada hari Rabu, 8 Juni 2011.

http://edukasi.kompas.com, diakses pada hari Rabu, 8 Juni 2011.

http://www.republika.co.id. Diakses pada hari rabu, 8 Juni 2011.

Kompas, 31 Maret 2011.

Karol, Nathaniel H. \& Ginsburg, Sigmund G., Managing The Higher Education Enterprise, t.p.: t.th.

Nazaruddin, Manajemen Pembelajaran: Implementasi Konsep, Karakteristik dan Metodologi Pendidikan Agama Islam di Sekolah Umum, Yogyakarta: Teras, 2007.

Prabwa, Andi Haris dkk., Paradigma Pengembangan Kurikulum 2000, Surakarta: UMS Press,2002. 
Sallis, Edward, Total Quality Management dalam Konteks Pendidikan, Yogyakarta: IRCiSoD. 2010.

Suyanto, Slamet, "Pengembangan Sekolah Bertaraf Internasional (SBI) Melalui Organisasi Belajar: Konsep dan Implementasi," http://www.apsihimpsi.org/download-document/3-SBI.php, diakses pada tanggal 12 November 2008.

Tilaar, H.A.R., Manajemen Pendidikan Nasional; Kajian Pendidikan Masa Depan, Bandung: Remaja Rosdakarya, 1999. 
